Gazi University
Journal of Science
http://dergipark.gov.tr/gujs

\title{
Design and Experimental Investigation of Modified Switched Coupled Inductor Quasi Z-Source Cascaded Multilevel Inverter
}

\author{
Raghavendra Rajan VIJAYARAGHAVAN (D), Premalatha LOGAMANI* \\ School of Electrical Engineering, Vellore Institute of Technology, Chennai, India - 600127
}

\author{
Highlights \\ - Implementing Nearest Level Modulation technique to modified SCL qZS-CMI. \\ - Voltage gain vs switching stress is analyzed. \\ - Simulation results are analyzed with existing quasi Z-Source Cascaded Multilevel Inverter. \\ - Prototype model is designed for modified SCL qZS-CMI and analyzed.
}

\begin{tabular}{l} 
Article Info \\
\hline \\
Received: $30 / 04 / 2019$ \\
Accepted: 11/09/2019 \\
Keywords \\
\hline Switched Coupled \\
Inductor quasi Z-Source \\
Cascaded Multilevel \\
Inverter \\
Nearest level modulation
\end{tabular}

\begin{abstract}
This paper proposes Switched coupled inductor (SCL) based quasi-Z- Source cascaded multilevel inverter (qZS-CMI), (SCL qZS-CMI) using nearest level modulation (NLM) technique in this paper. The proposed inverter introduces appealing advantages over conventional qZS-CMI such as lower component voltage stress, improved output power quality and efficiency. Both simulation and experimental verification have been carried out for SCL qZS-CMI with a power rating of $250 \mathrm{~W}$ to validate the above claims.
\end{abstract}

\section{INTRODUCTION}

Traditional Voltage-source-inverter (VSI) and Current-source-inverter (CSI) have a huge demand in industrial applications but still, face some disadvantages. VSIs can implement only buck operation while CSIs can perform only voltage boost inversion [1]. To quell the drawbacks of VSI and CSI, Z-Source Inverter (ZSI) is introduced [2]. ZSI performs a single-stage operation for buck and boost in voltage conversion. ZSI also easily accord a wide range of operation even though fluctuations are present, whereas in traditional dc-dc converter it is achieved in two-stage operation [3-5]. In improving ZSI further, it is integrated with Cascaded Multilevel Inverter (CMI) [6-7]. The main reason for choosing CMI over the other two types of MLI namely, Diode Clamped MLI and Flying Capacitor MLI are, the diode clamped MLI has more diodes with a combination of switches. Similarly, flying capacitor MLI has multiple capacitors with switches. The main advantage of CMI is, it has only switches, without any diodes and capacitors [8-10]. Z-Source-CMI (ZS-CMI) overcome the disadvantages of traditional CMI with singlestage inversion [11-14]. Further, with small inductance value, there will be a discontinuity in ZSI [15]. To overcome the above condition quasi Z-Source inverter (qZSI) and qZS-CMI have been introduced as shown in Figure 1. Consequently, by utilizing qZS-CMI many attempts are made to increase the boost capability by applying various PWM methods such as simple boost control, maximum boost control and constant boost control [16-17]. But these techniques have limitations over the boost capability of voltage. In sequence to boost the voltage, the only option is to improve the circuit with various circuit topologies such as switched-capacitor (SC), switched-inductor (SL) [18-22]. In further combination with switched capacitor and switched inductor is named as Switched Coupled Inductor quasi Z-Source Inverter, where it overcome 
the disadvantages which are present in above mentioned inverter topologies of quasi Z-Source network.By implementing quasi Z-Source Inverter to Neutral Point Clampped (NPC) it is more complex to deal with diodes of NPC and qZSI while increasing for higher levels.

In this paper, the integration of Switched coupled inductor (SCL) and qZS-CMI is proposed. Nearest Level Modulation (NLM) technique is applied to obtain pulses for switches because this method uses a large step number that helps to uplift the calibre of the output voltage [23]. This paper organizes as follows; Section 2-describes SCL qZS-CMI, Implementation of Nearest Level Modulation (NLM) technique is briefed in section 3, Simulation results are discussed in section 4, Verification and validation of experimental results are done in section 5, key results and inferences are discussed in section 6 .

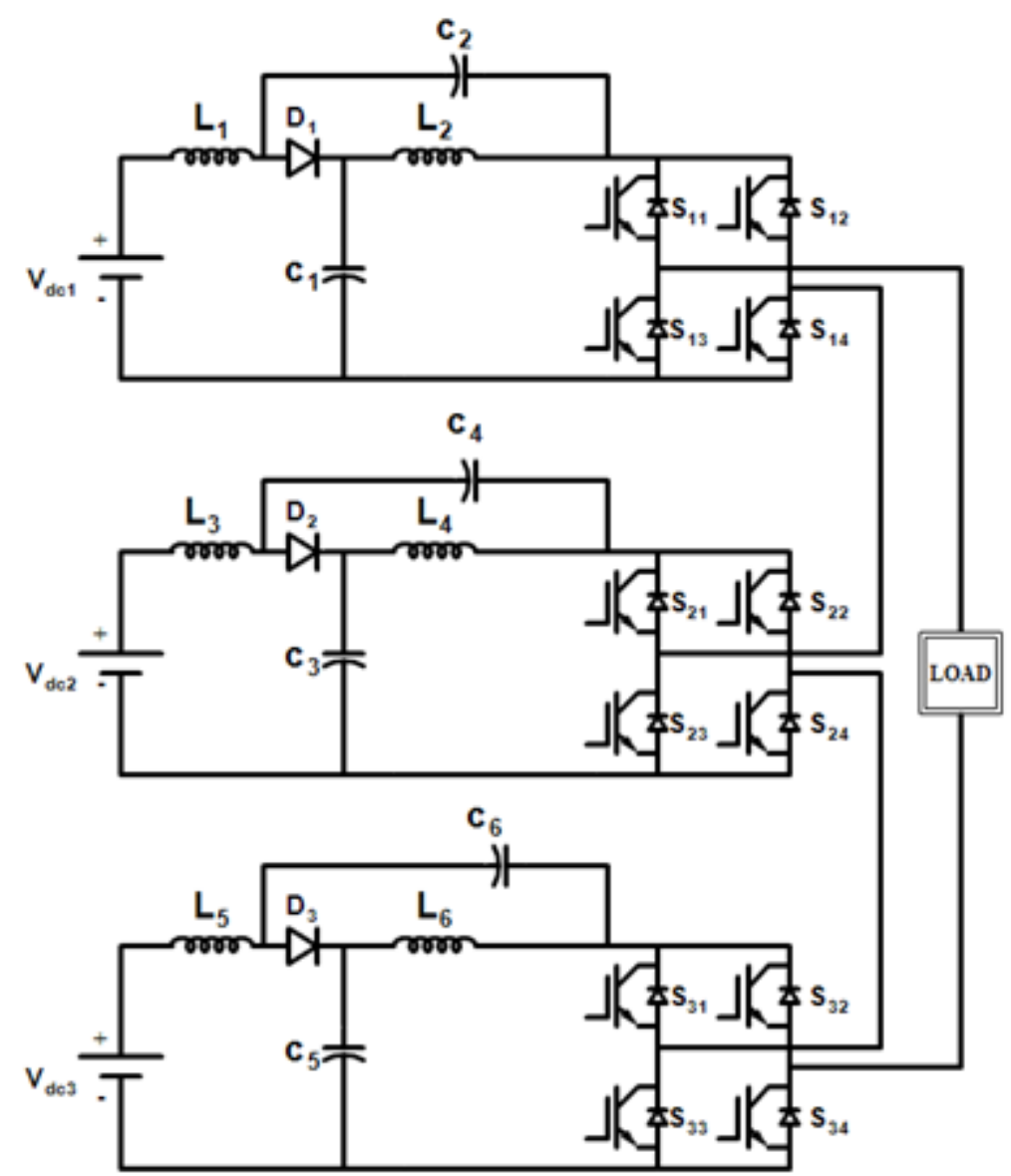

Figure 1. Quasi Z-Source Cascaded Multilevel Inverter

The existing quasi Z-Source Cascaded Multilevel Inverter is shown in Figure 1. The shoot-through time interval is $T_{s h}$, during switching period $T_{s}$, the shoot-through duty cycle is defined as $D=T_{s h} / T_{s}$.

$$
\begin{aligned}
& V_{C 1}=\frac{1-D}{1-2 D} V_{i n} \\
& V_{C 2}=\frac{D}{1-2 D} V_{i n} \\
& V_{D C}=V_{C 1}+V_{C 2}=\frac{1}{1-2 D} V_{i n}
\end{aligned}
$$

$V_{C 1}$ and $V_{C 2}$ are the voltages of capacitors 1 and $2, V_{i n}$ is the input voltage, where $V_{D C}$ is the DC link voltage. In non-shoot through there is no contribution of the voltage, where $V_{D C}=0$.

For qZS- CMI the synthesize voltage is; 


$$
V_{H}=\sum_{k=1}^{n} V_{h}=\sum_{k=1}^{n} S_{k} V_{i n}
$$

$V_{H}$ is the input voltage of the H-Bridge module, $V_{h}$ is the output voltage of the each H-Bridge module [23]. Figures 2 and 3 represents the shoot-through and non shoot-through operation of existing qZS-CMI.

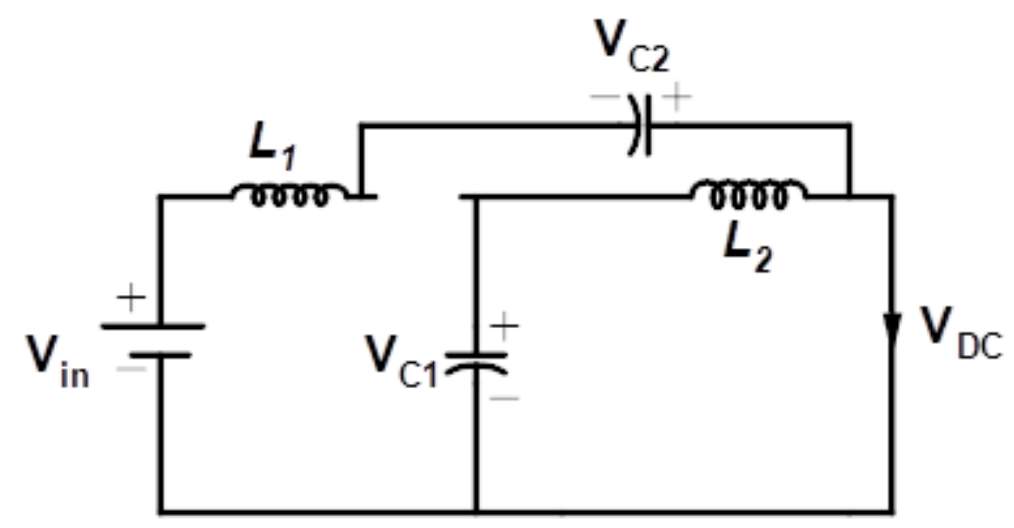

Figure 2. Shoot-through operation of qZS-CMI

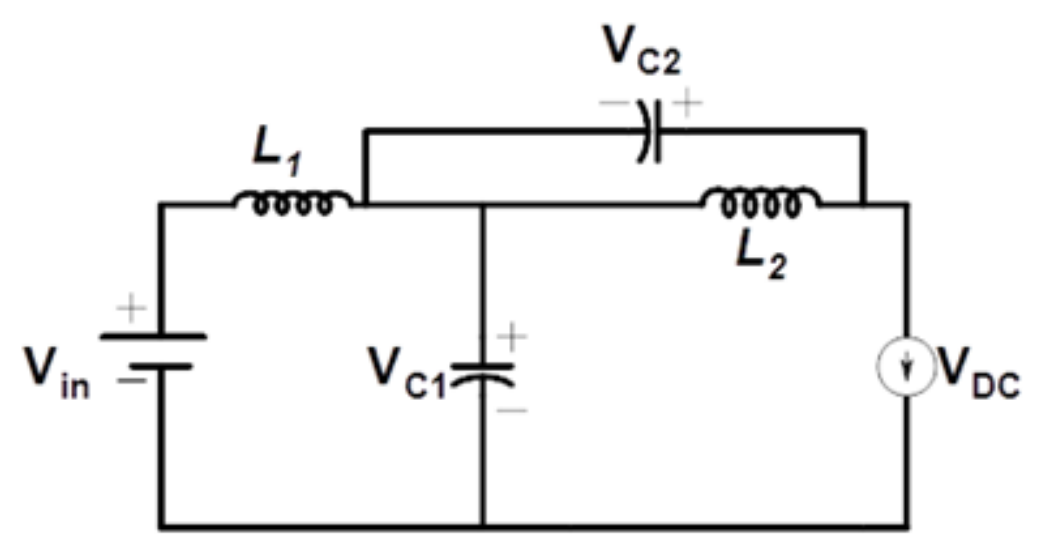

Figure 3.Non-shoot through operation of qZS-CMI

\section{MODIFIED SCL qZS-CMI}

In this proposed circuit, each $\mathrm{H}$-Bridge module has the same capacitor values and inductor values. In each $\mathrm{H}$-Bridge module, coupled inductor of each bridge is connected with a pair of diodes i.e., $\left(\mathrm{D}_{2}, \mathrm{D}_{3}\right),\left(\mathrm{D}_{5}, \mathrm{D}_{6}\right)$ and $\left(D_{8}, D_{9}\right)$ as shown in Figure 4. The coupled inductor has the same no.of turns with $\mathrm{N}_{\mathrm{xa}}=\mathrm{N}_{\mathrm{xb}}$ turns ratio of winding is $n=N_{x c} / N_{x a}=N_{x c} / N_{x b}$. The turn's ratio of windings is the same for the other two H-bridges.

SCL combines with one capacitor, two diodes in the existing model. It achieves high boost factor of 3/ (14D) in comparing with traditional qZS-CMI . SCL has low stress on the components of the circuit. By comparing with the traditional qZS-CMI [24] the size of the inductor is reduced. SCL qZS-CMI will operate in shoot-through and non-shoot-through states. In shoot-through state, which is shown in Figure 5, diodes $D_{1}, D_{4}, D_{7}$ will be OFF. whereas diodes $\left(D_{2}, D_{3}\right),\left(D_{5}, D_{6}\right)$ and $\left(D_{8}, D_{9}\right)$ will be ON. Windings $\left(N_{\text {ха }}\right.$ , $\left.\mathrm{N}_{\mathrm{xb}}\right),\left(\mathrm{N}_{\mathrm{ya}}, \mathrm{N}_{\mathrm{yb}}\right)$ and $\left(\mathrm{N}_{\mathrm{za}}, \mathrm{N}_{\mathrm{zb}}\right)$ are charged by parallel capacitors $\mathrm{C}_{1}, \mathrm{C}_{4}, \mathrm{C}_{7} \cdot \mathrm{N}_{\mathrm{xc}}, \mathrm{N}_{\mathrm{yc}}$ and $\mathrm{N}_{\mathrm{zc}}$ produces energy to $\mathrm{C}_{1}, \mathrm{C}_{4}, \mathrm{C}_{7}$ and capacitors $\mathrm{C}_{3}, \mathrm{C}_{6}, \mathrm{C}_{9}$ will obtain energy. The leakage inductance is limited by charging current of capacitors $\mathrm{C}_{3}, \mathrm{C}_{6}, \mathrm{C}_{9}$. 


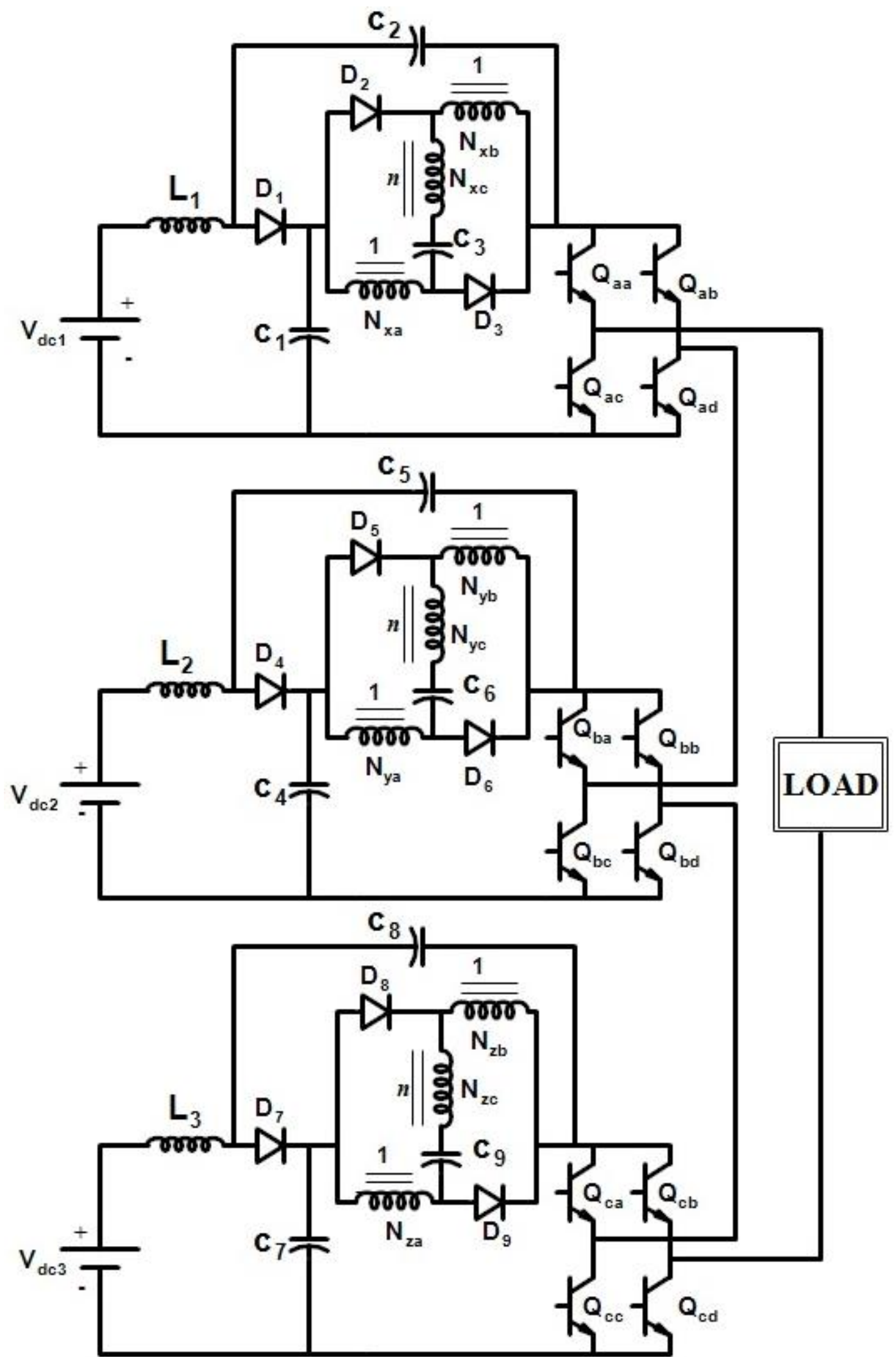

Figure 4. Circuit diagram of proposed SCL qZS-CMI 


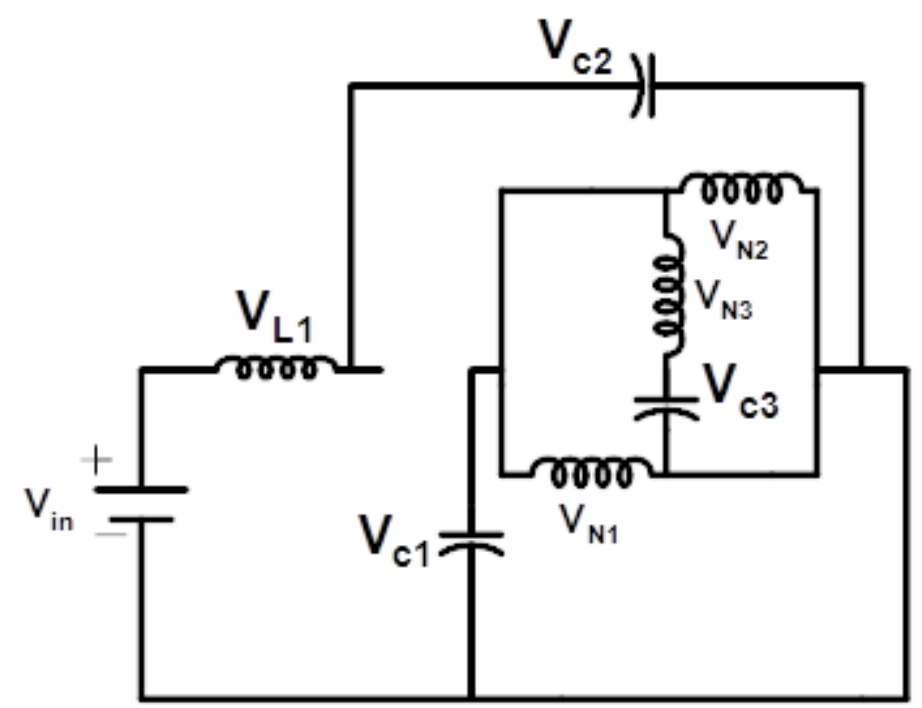

Figure 5. Shoot-through of the proposed modified SCL qZS-CMI

During non-shoot-through, it has six operating states and two non-operating states for SCL qZS-CMI. Diodes $\left(D_{2}, D_{3}\right),\left(D_{5}, D_{6}\right)$ and $\left(D_{8}, D_{9}\right)$ will be OFF, diodes $D_{1}, D_{4}, D_{7}$ will be ON. The capacitors $\left(C_{1}, C_{2}\right)$, $\left(\mathrm{C}_{4}, \mathrm{C}_{5}\right)$ and $\left(\mathrm{C}_{7}, \mathrm{C}_{8}\right)$ will be charged. The windings $\left(\mathrm{N}_{\mathrm{xa}}, \mathrm{N}_{\mathrm{xb}}, \mathrm{N}_{\mathrm{xc}}\right),\left(\mathrm{N}_{\mathrm{ya}}, \mathrm{N}_{\mathrm{yb}}, \mathrm{N}_{\mathrm{yc}}\right)$ and $\left(\mathrm{N}_{\mathrm{za}}, \mathrm{N}_{\mathrm{zb}}, \mathrm{N}_{\mathrm{zc}}\right)$ are in series with capacitors $\mathrm{C}_{3}, \mathrm{C}_{6}, \mathrm{C}_{9}$ to transfer energy to the main circuit. The leakage inductance of SCL qZS$\mathrm{CMI}$ is absorbed by $\mathrm{C}_{2}, \mathrm{C}_{5}$, and $\mathrm{C}_{8}$ and recycled to avoid stress on switches. SCL qZS-CMI produces a step waveform with the smooth quality of output voltage. Non shoot- through operation is shown in Figure 6.

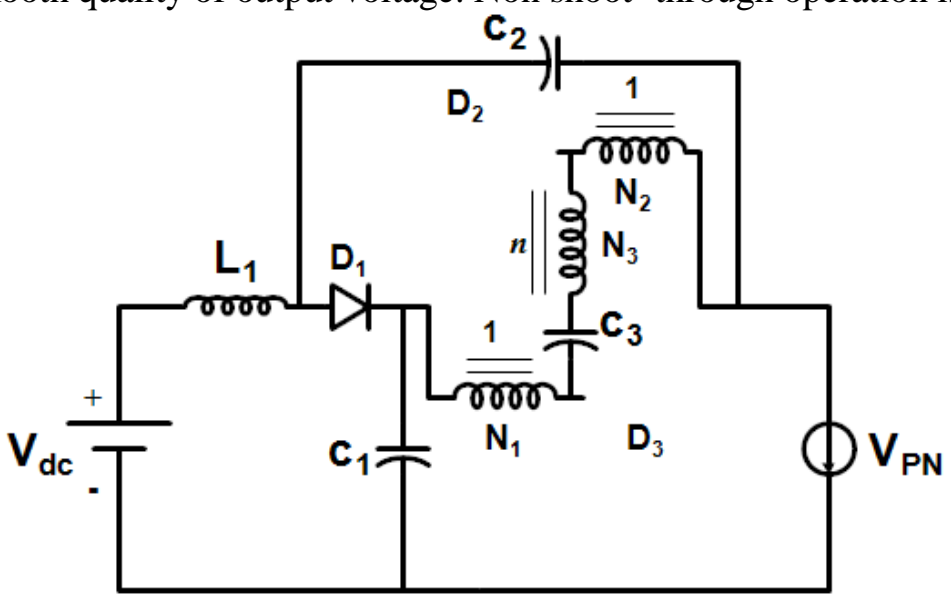

Figure 6. Non shoot-through of the proposed modified SCL qZS-CMI

The reason for separate DC sources is the CMI connection needs separate DC sources initially. The switching sequence for SCL qZS-CMI is given in Table 1.

SCL qZS-CMI is connected in series with individual dc sources. The switch count of the circuit is ' $4 \mathrm{n}$ ' where ' $\mathrm{n}$ ' is no.of dc sources. Three dc sources have the same voltage and the AC output voltage is attained by $2 n+1$ levels. The equation of SCL qZS-CMI with DC source is given as;

$V_{d c g}=V_{d c}$, where $\mathrm{g}=1,2,3, \ldots, \mathrm{n}$. The voltage level of three H-Bridge of SCL qZS-CMI is generated as follows:

$\mathrm{V}_{\mathrm{dc} 1}$ for $\mathrm{V}_{\mathrm{dcm}}, \mathrm{V}_{\mathrm{dc} 1}+\mathrm{V}_{\mathrm{dc} 2}$ for $2 \mathrm{~V}_{\mathrm{dcm}}$ and $\mathrm{V}_{\mathrm{dc} 1}+\mathrm{V}_{\mathrm{dc} 2}+\mathrm{V}_{\mathrm{dc} 3}$ for $3 \mathrm{~V}_{\mathrm{dcm}}$.

In comparison, the switching stress of voltage vs voltage gain for qZS-CMI and SCL qZS-CMI is shown in Figure 7. In terms of switching stress and voltage gain for SCL qZS-CMI, it is given as, where $\mathrm{V}_{\mathrm{g}}$ is Voltage gain and $\mathrm{V}_{\mathrm{sw}}$ is switching stress; 


$$
V_{S W}=\left(\frac{4 V_{g}-3}{3}\right) V_{i n}
$$

Table 1. Switching Sequence of modified SCL qZS-CMI

\begin{tabular}{|c|c|c|c|c|c|c|c|c|}
\hline$\stackrel{\text { Soltage }}{\stackrel{\text { Switch }}{\downarrow}}$ & 0 & $\mathrm{~V}_{\mathrm{dcm}}$ & $2 \mathrm{~V}_{\mathrm{dcm}}$ & $3 \mathrm{~V}_{\mathrm{dcm}}$ & $-3 V_{d c m}$ & $-2 V_{\mathrm{dcm}}$ & $-\mathrm{V}_{\mathrm{dcm}}$ & 0 \\
\hline $\mathrm{Q}_{\mathrm{aa}}$ & ON & $\mathrm{ON}$ & $\mathrm{ON}$ & ON & OFF & OFF & OFF & OFF \\
\hline $\mathrm{Q}_{\mathrm{ab}}$ & $\mathrm{ON}$ & OFF & OFF & OFF & $\mathrm{ON}$ & $\mathrm{ON}$ & $\mathrm{ON}$ & OFF \\
\hline $\mathrm{Q}_{\mathrm{ac}}$ & OFF & OFF & OFF & OFF & $\mathrm{ON}$ & $\mathrm{ON}$ & ON & $\mathrm{ON}$ \\
\hline $\mathrm{Q}_{\mathrm{ad}}$ & OFF & $\mathrm{ON}$ & $\mathrm{ON}$ & $\mathrm{ON}$ & OFF & OFF & OFF & $\mathrm{ON}$ \\
\hline $\mathrm{Q}_{\mathrm{ba}}$ & $\mathrm{ON}$ & ON & ON & ON & OFF & OFF & OFF & OFF \\
\hline $\mathrm{Q}_{\mathrm{bb}}$ & $\mathrm{ON}$ & $\mathrm{ON}$ & OFF & OFF & $\mathrm{ON}$ & $\mathrm{ON}$ & OFF & OFF \\
\hline $\mathrm{Q}_{\mathrm{bc}}$ & OFF & OFF & OFF & OFF & $\mathrm{ON}$ & $\mathrm{ON}$ & $\mathrm{ON}$ & ON \\
\hline $\mathrm{Q}_{\mathrm{bd}}$ & OFF & OFF & ON & $\mathrm{ON}$ & OFF & OFF & $\mathrm{ON}$ & $\mathrm{ON}$ \\
\hline $\mathrm{Q}_{\mathrm{ca}}$ & $\mathrm{ON}$ & $\mathrm{ON}$ & ON & ON & OFF & OFF & OFF & OFF \\
\hline $\mathrm{Q}_{\mathrm{cb}}$ & ON & $\mathrm{ON}$ & ON & OFF & $\mathrm{ON}$ & OFF & OFF & OFF \\
\hline $\mathrm{Q}_{\mathrm{cc}}$ & OFF & OFF & OFF & OFF & ON & $\mathrm{ON}$ & ON & ON \\
\hline $\mathrm{Q}_{\mathrm{cd}}$ & OFF & OFF & OFF & $\mathrm{ON}$ & OFF & $\mathrm{ON}$ & $\mathrm{ON}$ & $\mathrm{ON}$ \\
\hline
\end{tabular}

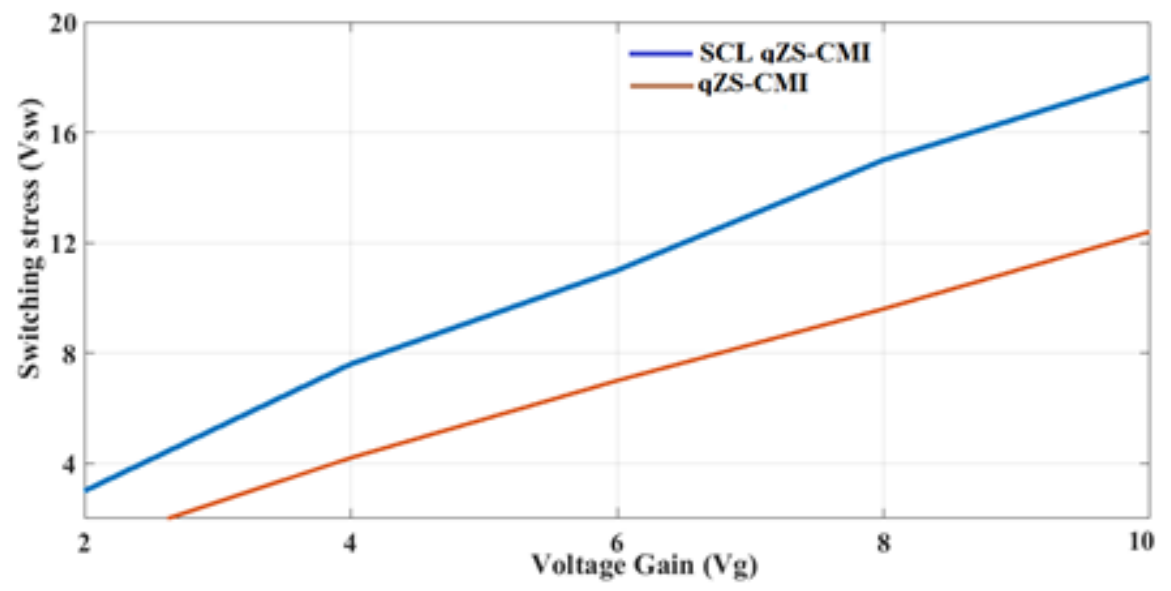

Figure 7. The plot of Voltage Gain vs Switching stress

\section{NEAREST MODULATION TECHNIQUE}

This technique directly controls the phase voltage of the inverter and keeps it constant [25-27]. Also, this technique has less grievance in computation and has more flexibility in choosing the pattern of switching operation. The nearest-level modulation technique regulates in two switching modes such as increment and decrement mode as shown in Figure 8(a),(b). 


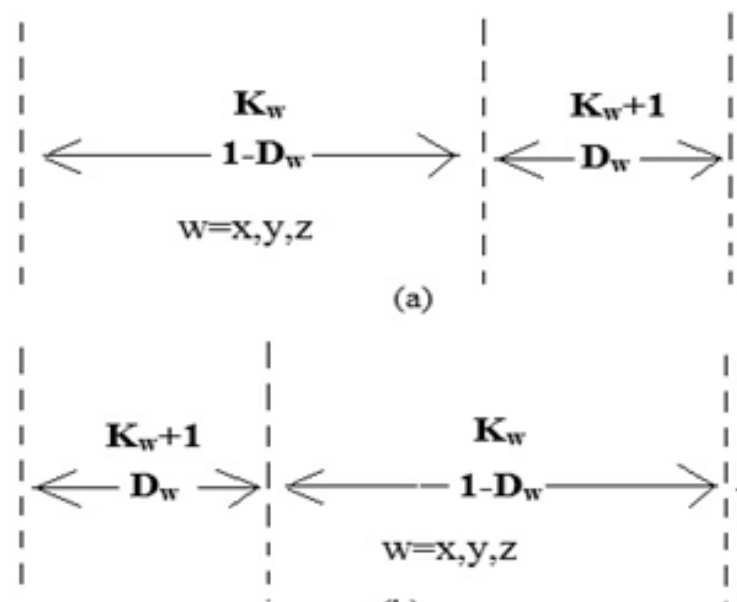

(b)

Figure 8. Nearest Level Modulation Technique :(a)Incremental operation,(b) Decremental operation

The switching pattern of each phase is incremented from $K_{w}$ to $K_{w+1}$, and decremented from $K_{w+1}$ to $K_{w}$ to alleviate the harmonics in phase voltages for increment and decrement modes, the switching pattern should be similar for each cycle [28].The general equation for NLM technique is;

$x_{i}=\arcsin \left(\frac{1-0.5}{n}\right) ;$ for $\mathrm{i}=1,2,3, \ldots \mathrm{n}$

where $n=\frac{l-1}{2}$,

$l=$ number of levels in modified SCL qZS-CMI. For a 7 level cascaded multilevel inverter, $\mathrm{n}=3$. On substituting the value of $l$ in (6), the switching angles obtained are $x_{1}=9.60^{\circ}, x_{2}=30.00^{\circ}, x_{3}=56.44^{\circ}$. The NLM technique can also be used in high voltage applications. NLM is used in CMI for controlling the output voltage easily.

\section{SIMULATION RESULTS}

In prior to the experimental verification, simulation of the existing toplogy qZS-CMI and proposed SCL qZS-CMI is performed. The inductors value and capacitors value of qZS-CMI are taken based on literature [24]. The value of capacitors and inductors for the dc link in the proposed topology is considered based on literature [19]. The coupled inductors are in the ratio 1:2:2 with the no.of turns $\mathrm{N}$, where the inductor value of the coupled inductor is $200 \mathrm{uH}$, and the switching frequency, $\mathrm{f}_{\mathrm{s}}=10 \mathrm{kHz}$. Here the R-load is considered for calculations. Tables 2 and 3 represents the values of existing qZS-CMI and proposed SCL qZSCMI.

Table 2. Parameter values of the existing qZS-CMI

\begin{tabular}{|l|l|l|}
\hline S.No & Parameter & Value \\
\hline 1 & Inductor $\left(\mathrm{L}_{1}\right.$ to $\left.\mathrm{L}_{6}\right)$ & $760 \mu \mathrm{H}$ \\
\hline 2 & Capacitor $\left(\mathrm{C}_{1}\right.$ to $\left.\mathrm{C}_{6}\right)$ & $4400 \mu \mathrm{F}$ \\
\hline
\end{tabular}

Table 3. Parameter values of the proposed modified SCL qZS-CMI

\begin{tabular}{|l|l|l|}
\hline S.No & Parameter & Value \\
\hline 1 & Inductors $\left(\mathrm{L}_{1}\right.$ to $\left.\mathrm{L}_{3}\right)$ & $500 \mu \mathrm{H}$ \\
\hline 2 & Capacitors $\left(\mathrm{C}_{1}\right.$ to $\left.\mathrm{C}_{8}\right)$ & $440 \mu \mathrm{F}$ \\
\hline 3 & Coupled Inductor $(1: 2: 2)$ & $200 \mu \mathrm{H}$ \\
\hline
\end{tabular}




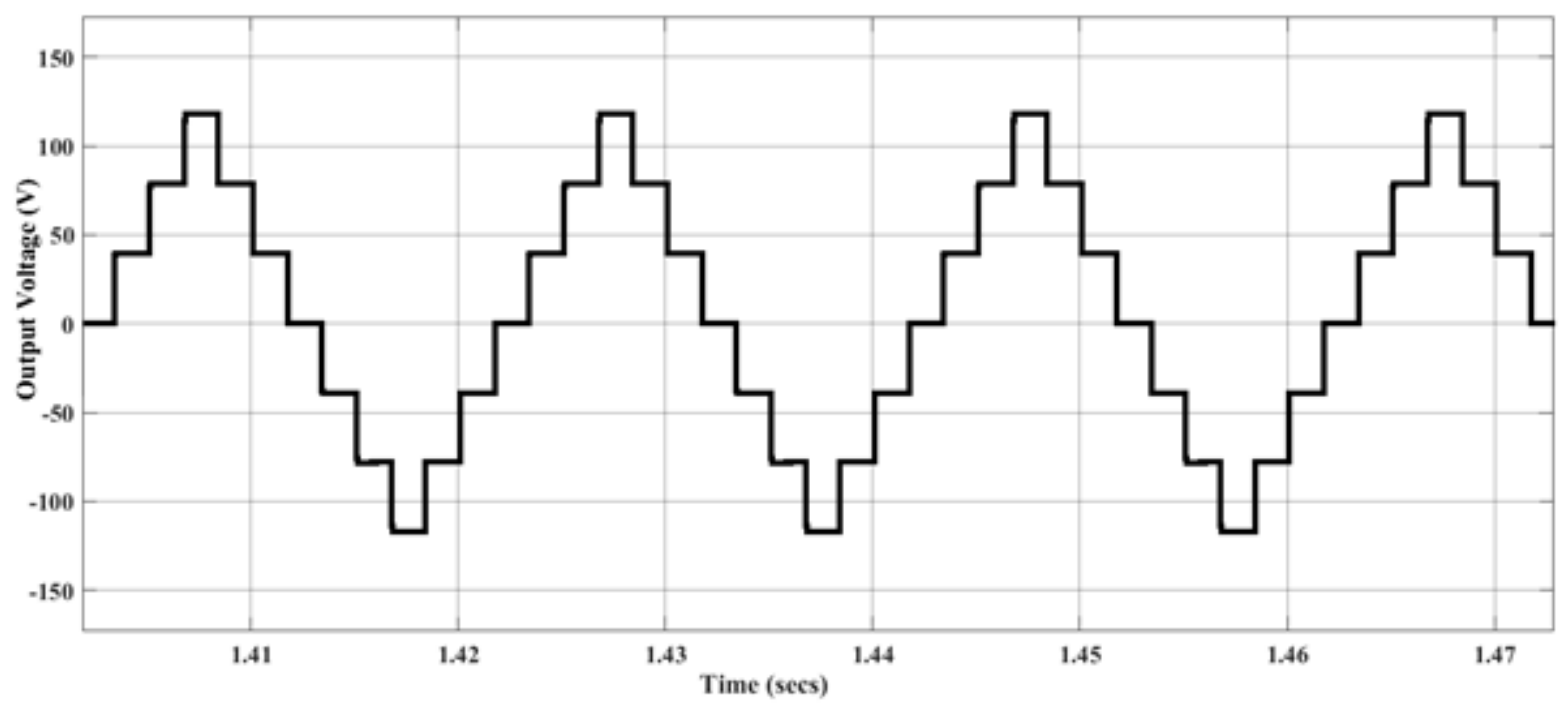

Figure 9. Simulation output voltage of $q Z S-C M I$

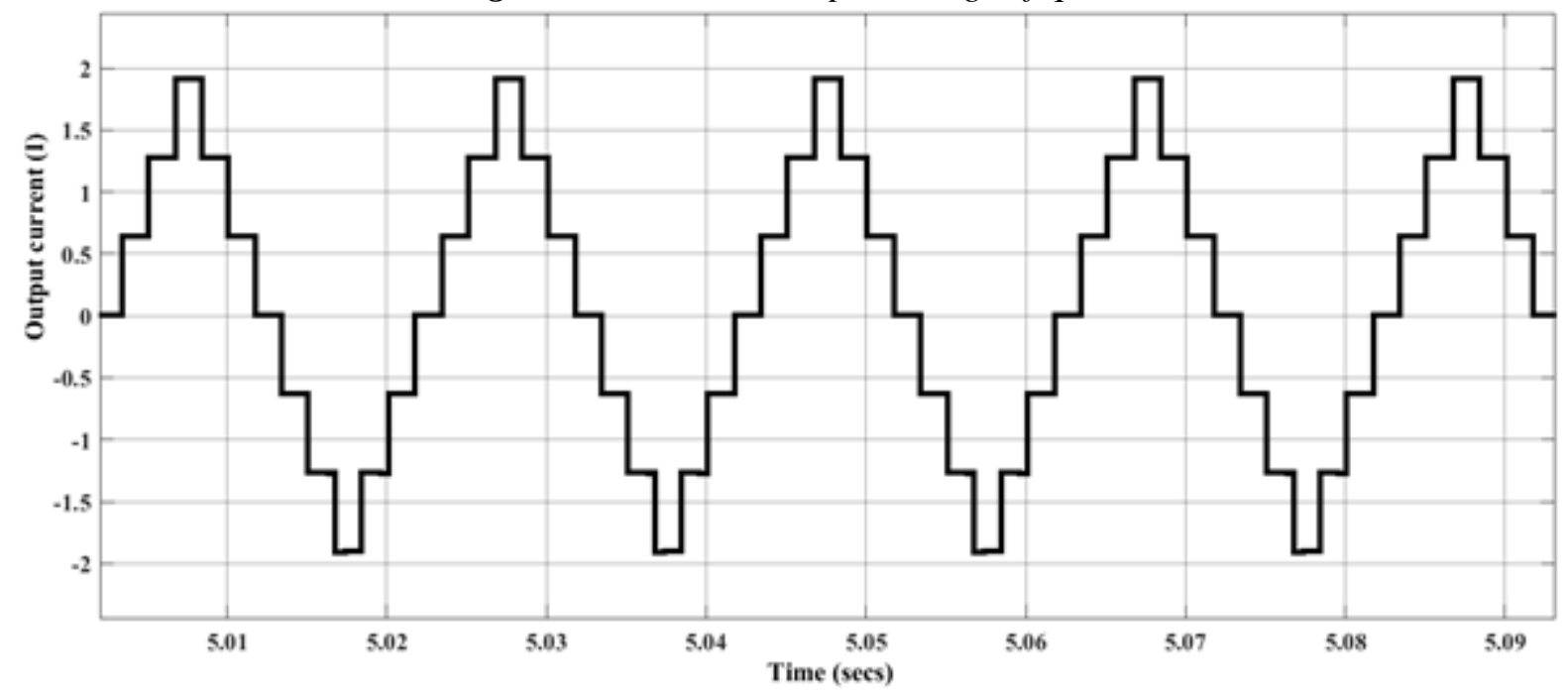

Figure 10. Simulation output current of $q Z S-C M I$

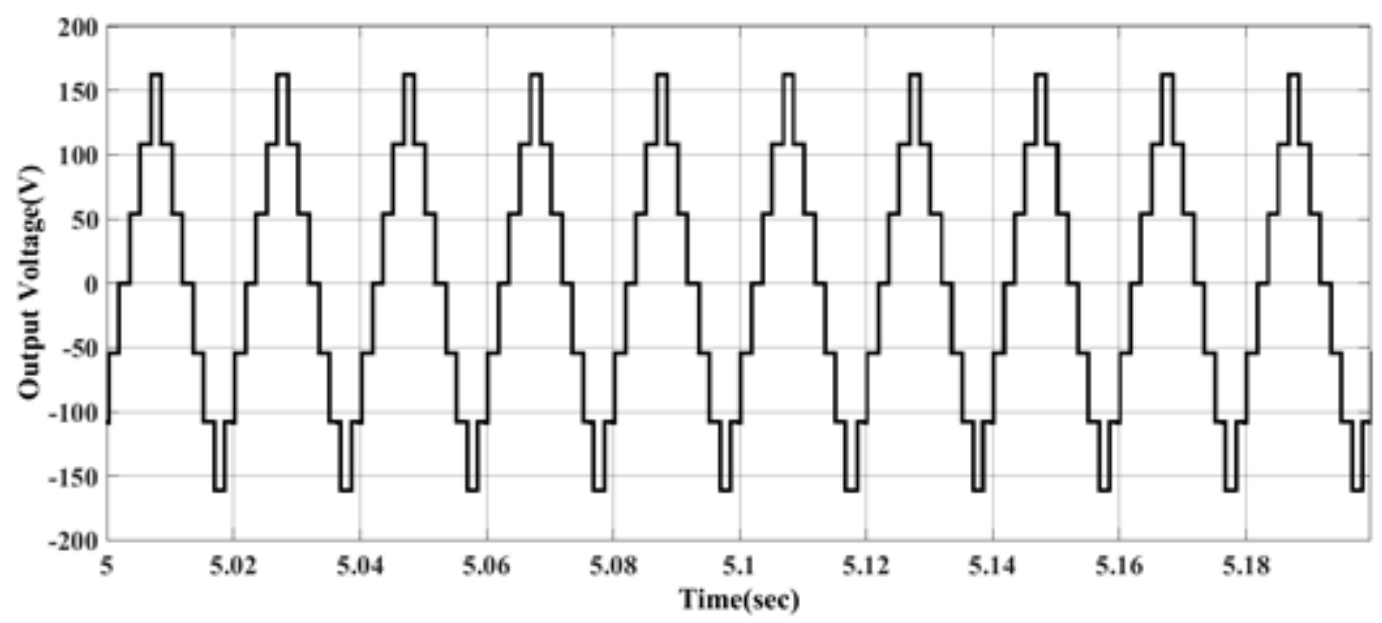

Figure 11. Simulation output voltage of proposed modified SCL qZS-CMI

The simulation results of output voltage and output current of existing qZS-CMI are shown in Figures 9 and 10. The ouput voltage of the qZS-CMI is $114.4 \mathrm{~V}$ and output current is 1.98A. 
The simulation results of the output voltage and the output current are shown in Figures 11 and 12. The output voltage is $166.6 \mathrm{~V}$ and the output current is $1.4 \mathrm{~A}$. The output voltage of the existing qZS-CMI is boosted 1.25 times of the given input voltage, where as the proposed topology SCL qZS- CMI is boosted 1.85 times of the input voltage. The SCL qZS-CMI is increased due to the presence coupled inductor in the circuit.

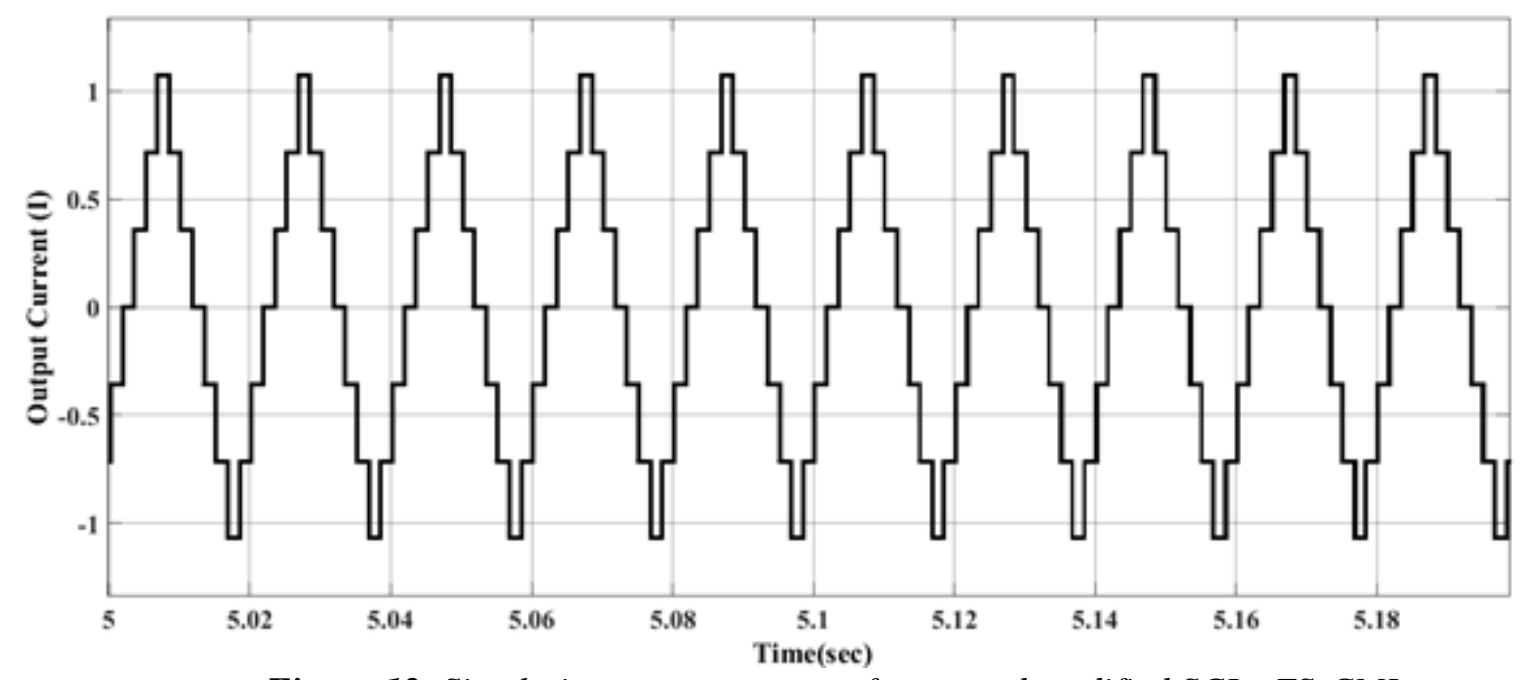

Figure 12. Simulation output current of proposed modified SCL qZS-CMI

The system is designed for R-load. THD comparison is shown in Figures 13 and 14, which is represented using FFT analysis. In comparison of THD, the traditional qZS-CMI has 3.33\% and proposed modified SCL qZS-CMI has $2.18 \%$.

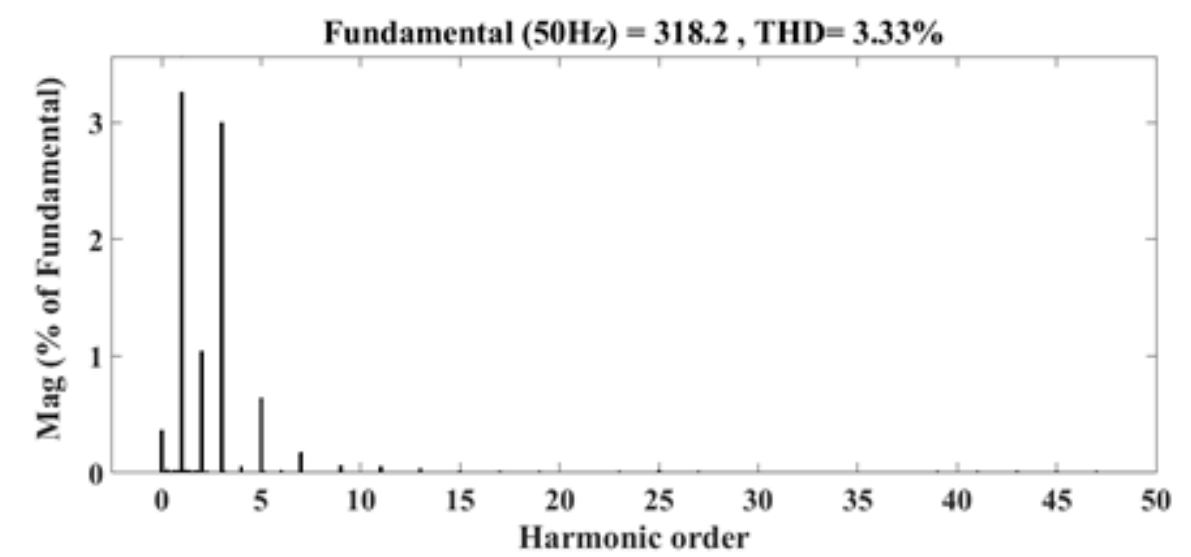

Figure 13. Voltage THD of qZS-CMI

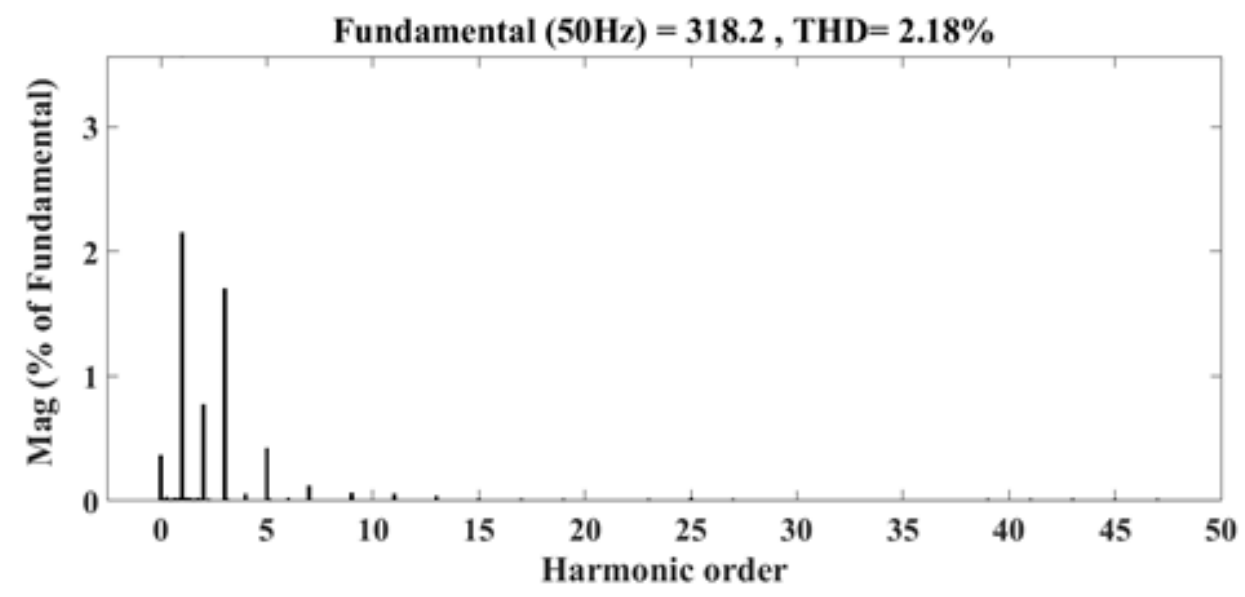

Figure 14. Voltage THD of modified SCL qZS-CMI 
For traditional qZS-CMI and proposed modified SCL qZS-CMI the values of $C_{f}=2000 \mathrm{uF}$ and $L_{f}=5 \mathrm{mH}$ are used for the filter. The equation used for calculating the values of capacitor and inductor for the filter are as follows

$$
\begin{gathered}
f=\frac{1}{2 \Pi \sqrt{L_{f} C_{f}}}, \\
C_{f}=\left(\frac{1}{2 \Pi * 50 \sqrt{5 * 10^{-3}}}\right)^{2} .
\end{gathered}
$$

By considering $L_{f}$ as $5 \mathrm{mH}$ and substituting in (4), $C_{f}$ is found as, $C_{f}=200 \mathrm{uF}$. The output voltage with the filter of the proposed SCL qZS-CMI is shown in Figure 15.

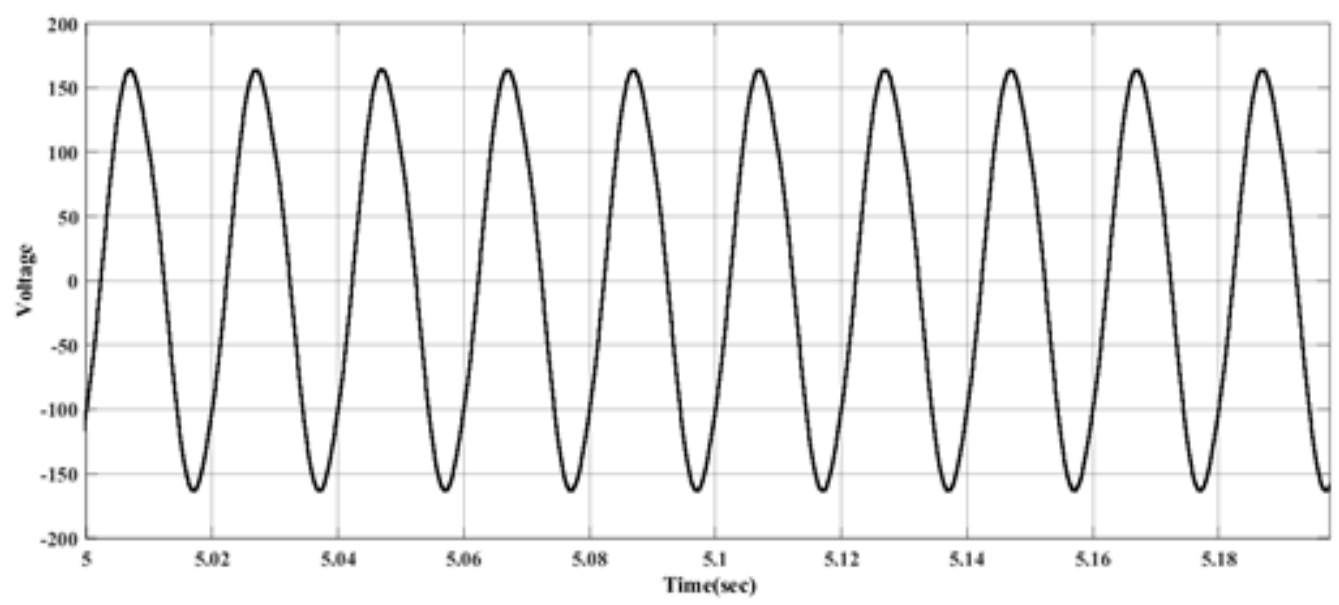

Figure 15. Simulation output voltage of modified SCL qZS-CMI with the filter

\section{EXPERIMENTAL RESULTS}

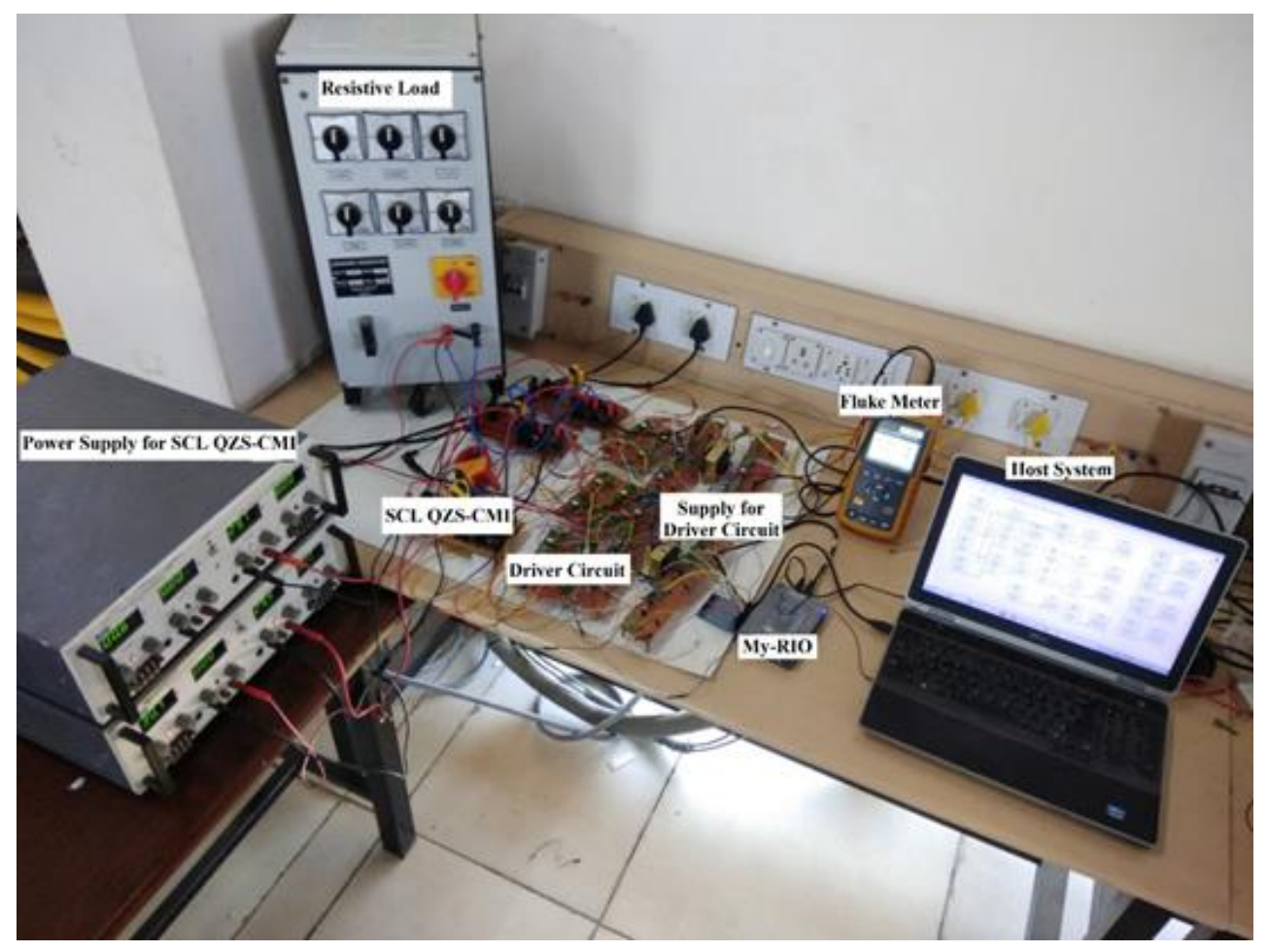

Figure 16. Experimental setup of modified SCL qZS-CMI 
Experimental validation 250W is performed for the proposed modified SCL qZS-CMI. My-RIO (National Instruments) board is utilized to implement the control scheme (NLM technique). Apart from My-RIO, the proposed system is built with TLP-350 optocoupler driver circuit. The TLP-350 driver circuit is used for driving the pulses to the switches through connecting My-RIO pins.

The power supply for driver circuit is given by using transformer $230 / 18 \mathrm{~V}$ and it is stepped down to DC $15 \mathrm{~V}$ which is sufficient for TLP-350. In Figure 16 the experimental setup of modified SCL qZS-CMI is shown. The parameters chosen for the proposed modified SCL qZS-CMI are the same that have been implemented in simulation. In the experimental setup, the switches used are IGBT H20R1203. In detail the input voltage for each module is given as $30 \mathrm{~V}$ and combining of the three sources, the total input voltage is $90 \mathrm{~V}$.

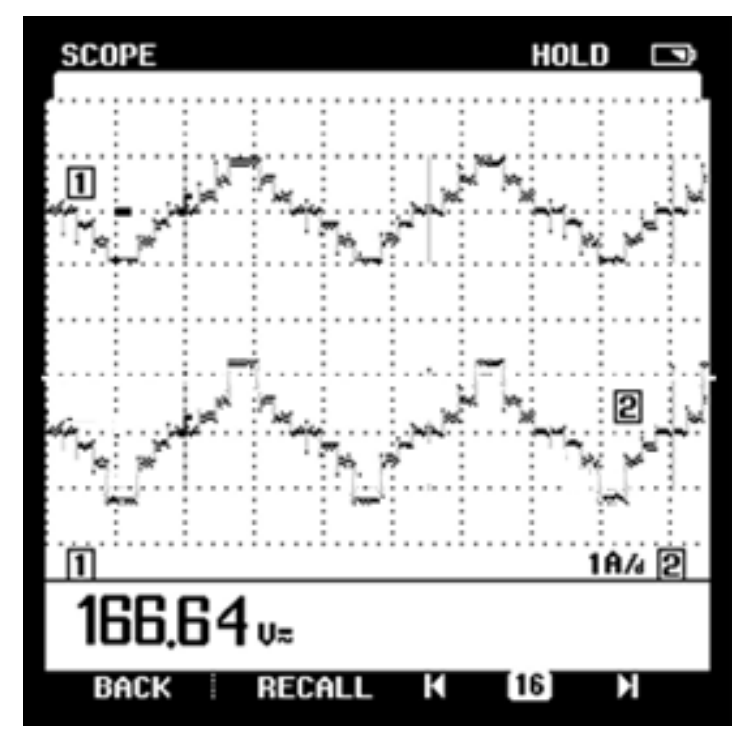

Figure 17. Experimental output voltage of modified SCL qZS-CMI

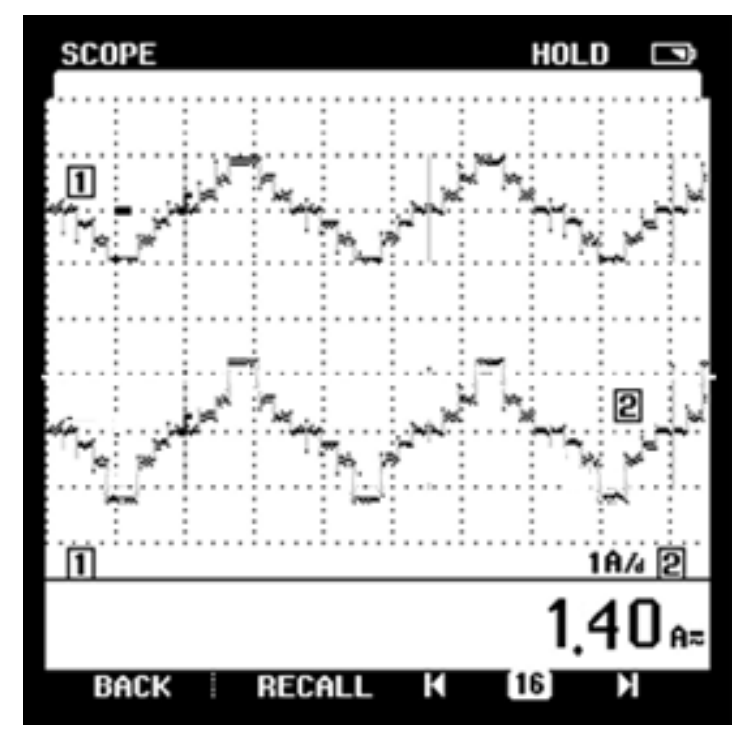

Figure 18. Experimental output current of modified SCL qZS-CMI

The output voltage is $166.64 \mathrm{~V}$ and the output current is $1.40 \mathrm{~A}$ are shown in Figures 17 and 18. In detail, the output voltage is boosted 1.85 times the input voltage. 


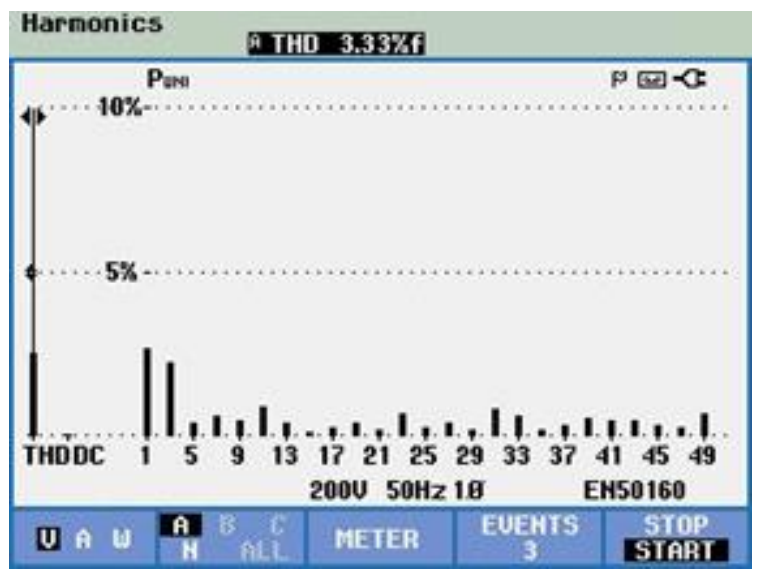

Figure 19. qZS-CMI experimental value of voltage THD

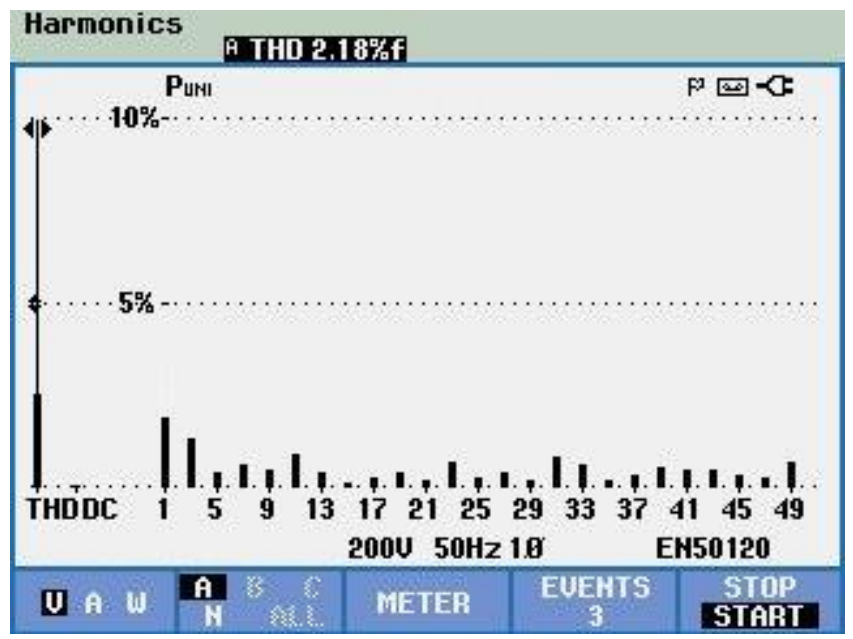

Figure 20. Modified SCL qZS-CMI experimental value of voltage THD

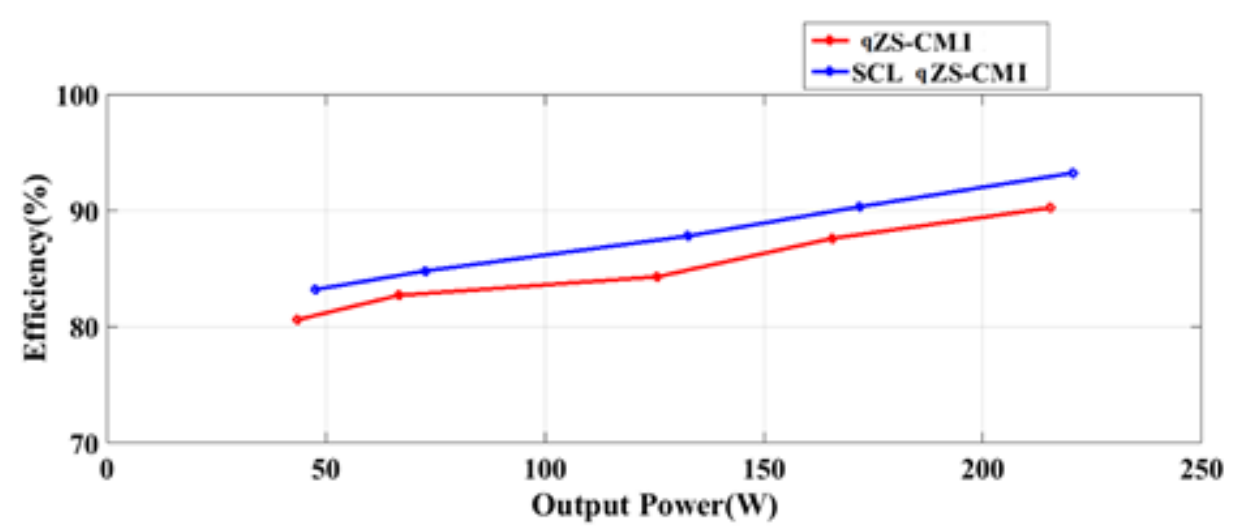

Figure 21. Efficiency comparison between qZS-CMI with the proposed modified

$$
\text { SCL } q Z S-C M I
$$

The comparative analysis for THD is done by utilizing single-phase power quality analyser, where the THD of qZS-CMI is 3.33\% and modified SCL qZS-CMI is $2.18 \%$, which are shown in Figures 19 and 20. Due to the smooth waveform and lower component rating in the proposed topology, the THD is getting reduced.

The efficiency is calculated based on the input power $\left(\mathrm{P}_{\mathrm{dc}}\right)$ and output power $\left(\mathrm{P}_{\mathrm{ac}}\right)$. The efficiency calculation of the existing system is as follows; 


$$
\begin{gathered}
\text { Efficiency }(\mathfrak{y})=\frac{P_{a c}}{P_{d c}}, \\
\mathfrak{y}=\frac{V_{a c} * I_{a c}}{V_{d c} * I_{d c}}=\frac{114.46 * 1.98}{90 * 2.76}=90.23 \% .
\end{gathered}
$$

In calculating the efficiency, proposed topology SCL qZS-CMI, input voltage of the system is $90 \mathrm{~V}$ and input current of $2.76 \mathrm{~A}$. The output voltage of the proposed topology is $166.64 \mathrm{~V}$ and $1.4 \mathrm{~A}$. Efficiency calculation of the proposed system;

$$
\mathfrak{y}=\frac{166.64 * 1.4}{90 * 2.76}=93.34 \% \text {. }
$$

In comparison, the efficiency is shown in Figure 21, the traditional qZS-CMI is $90.23 \%$ and proposed modified SCL qZS-CMI is $93.34 \%$.

\section{CONCLUSION}

This paper has proposed, modified SCL qZS-CMI. Performance analysis is done by comparing with traditional qZS-CMI for switching stress,THD and efficiency. The parameters are well designed and the experimental setup is built for proposed modified SCL qZS-CMI with a power rating of $250 \mathrm{~W}$. The proposed system is built for seven-level output voltage by implementing low frequency NLM technique. Simulation and experimental results are found to be same for proposed modifeied SCL qZS-CMI. In terms of better efficiency and power quality, this can be utilized for tool box application. In future it can be implemented for weak grid application with renewable energy (PV) systems.

\section{CONFLICTS OF INTEREST}

No conflict of interest was declared by authors.

\section{REFERENCES}

[1] Errabelli, R.R., Mutschler, P., "Fault- tolerant voltage source inverter for permanent magnet drives", IEEE Transactions on Power Electronics, 27(2): 500-508, (2012).

[2] Peng, F.Z., “Z-source inverter”, IEEE Transactions on Industrial Applications, 39(2): 504-510, (2003).

[3] Tang, Y., Fu, D., Kan, J., Wan, T., "Dual switches dc / dc Converter With Three-Winding-Coupled Inductor and Charge Pump," IEEE Transactions on Power Electronics,31(1): 461-469, (2016).

[4] Li, W., He, X., "Review of nonisolated high-step-up dc/dc converters in photovoltaic grid-connected applications", IEEE Transactions on Industrial Applications, 58(4): 1239-1250,( 2011).

[5] Zhang, L., Xu, D., Shen, G., Chen, M., Ioinovici, A., Wu, X., “A high step-up dc to dc converter under alternating phase shift control for fuel cell power system," IEEE Transactions on Power Electronics, 30 (3): $310-324,(2014)$.

[6] Banaei, M.R., Dehghanzadeh, A.R., Salary, E., Khounjahan, H., Alizadeh R., "Z-source-based multilevel inverter with reduction of switches", IET Power Electronics, 5(3): 385-392, (2011).

[7] Banaei, M.R., Dehghanzadeh, A.R., Fazel, A., Oskouei, A. B., "Switching algorithm for single z-source boost multilevel inverter with ability of voltage control", IET Power Electronics, 6(7): 1350-1359, (2012). 
[8] Babaei, E., Gowgani, S.S., Sabahi, M., "A new cascaded multilevel inverter with series and parallel connection ability of dc voltage sources", Turkish Journal of Electrical Engineering and Computer Sciences, 23: 85-102, (2015).

[9] Chabni, F., Taleb, R., Helaimi, M., "ANN-based shepwm using a harmony search on a new multilevel inverter topology", Turkish Journal of Electrical Engineering and Computer Sciences, 25: 4867-4879, (2017).

[10] Toopchi Khosroshahi, M., Ajami, A., Mokhberdoran, A.O., Jannati Oskuee, M., "Multilevel hybrid cascade-stack inverter with substantial reduction in switches number and power losses", Turkish Journal of Electrical Engineering and Computer Sciences, 23: 987-1000, (2015).

[11] Ge, B., Abu-Rub, H., Peng, F., Lei, Q., de Almeida, A., Ferreira, F., Sun, D., Liu, L., “An energy stored quasi-z-source inverter for application to photovoltaic power system". IEEE Transactions on Industrial Applications, 60(10): 4468-4481, (2013).

[12] Vinnikov, D., Roasto, I., Strzelecki, R., Adamowicz, M., "Step-up DC/DC converters with cascaded quasi-z-source network", IEEE Transactions on Industrial Applications, 59(10): 3727-3736, (2012).

[13] Li, Y., Jiang, S., Cintron-Rivera, J.G., Peng, F.Z., "Modeling and control of quasi-z-source inverter for distributed generation applications", IEEE Transactions on Industrial Applications, 60(4): 1532-1541, (2013).

[14] Liu, Y., Ge, B., Abu-Rub, H., Peng, F.Z., "Control system design of battery-assisted quasi-z-source inverter for grid-tie photovoltaic power generation", IEEE Transactions on Sustain Energy, 4(4): 991001, (2013).

[15] Chauhan, A.K., Raghuram, M., and Singh, S. K., "Nonzero discontinuous inductor current mode in certain z-source converters," IEEE Transactions on Power Electronics, 33 (4): 2809-2814, (2018).

[16] Abdelhakim, A., "Modulation schemes of the three-phase impedance source inverters- Part I: classification and review," IEEE Transactions on Industrial Applications, 65 (8): 6309-6320, (2018).

[17] Sheshyekani, K., Afjei, E., Khajesalehi, J., Hamzeh, M., "Maximum constant boost approach for controlling quasi-z-source-based interlinking converters in hybrid ac-dc microgrids," IET Generation Transmission \& Distribution, 10 (4): 938-948, (2016).

[18] Chen, S., Lao, M., Hsieh,Y., Liang, T., Member, S., Chen, K., "A novel switched-coupled-inductor dcdc step-up converter and its derivatives," IEEE Transactions on Industry Applications, 51 (1): 309-314, (2015).

[19] Ahmed, H.F, Cha, H., Kim, S., Kim, H., Member, S., "Switched-coupled-inductor quasi-z-source inverter," IEEE Transactions on Power Electronics, 31(2): 1241-1254, (2016).

[20] Abbasi, M., Eslahchi, A.H., Mardaneh, M., "Two symmetric extended-boost embedded switchedinductor quasi z-source inverter with reduced ripple continuous input current," IEEE Transactions on Industrial Applications, 65(6): 5096-5104, (2018).

[21] Zhu, X., Zhang, B., Qiu, D., "Enhanced boost quasi-z-source inverters with active Switched-Inductor boost network," IET Power Electronics, 11(11): 1774-1787, (2018). 
[22] Ghodsi, M., Barakati, S.M., Wu, B., "Extended switched-inductor quasi-Z-source inverter: Modeling and prototype realization," International Transactions on Electrical Energy Systems, 29(3): 2744-2752, (2019).

[23] Hu, P., Jiang, D., “A Level-Increased Nearest Level Modulation Method for Modular Multilevel Converters", IEEE Transactions on Power Electronics, 30(4): 312-319, (2015).

[24] Liu, Y., Ge,B., Abu-Rub, H., Peng, F.Z., "An Effective Control Method for Quasi-Z-Source Cascade Multilevel Inverter-Based Grid-Tie Single-Phase Photovoltaic Power System," IEEE Transactions on Industrial Informatics, 10(1):399-407, (2014).

[25] Sabahi, M., Kangarlu, M.F., Babaei, E., "Dynamic voltage restorer based on multilevel inverter with adjustable dc-link voltage," IET Power Electronics, 7(3): 576-590, (2014).

[26] Lin, L., Lin, Y., He, Z., Chen, Y., Hu, J., Li, W., "Improved Nearest-Level Modulation for a Modular Multilevel Converter With a Lower Submodule Number," IEEE Transactions on Power Electronics, 31 (8): 5369-5377, (2016).

[27] Mmc, C., and Symbols, B., “A Simplified Nearest Level Control ( NLC ) Voltage Balancing Method for Modular Multilevel,” IEEE Transactions on Power Electronics, 30 (1): 450-462, (2015).

[28] Deng, Y., Harley, R.G., "Space-Vector versus Nearest-Level Pulse Width Modulation for Multilevel Converters", IEEE Transactions on Power Electronics, 30(6): 2962-2973, (2015). 